\title{
Jurist-Diction
}

Volume 4 No. 5, September 2021

\section{Problematika Pengaturan Organisasi Sayap Partai di Indonesia}

\author{
Muhammad Riyanto Zahri \\ riyantozahri@gmail.com \\ Universitas Airlangga
}

How to cite:

Muhammad Riyanto Zahri, 'Problematika Pengaturan Organisasi Sayap Partai di Indonesia' (2021) Vol. 4 No. 5 Jurist-Diction

Histori artikel:

Submit 10 Juli 2021;

Diterima 15 Agustus 2021;

Diterbitkan 1 September 2021.

DOI:

10.20473/jd.v4i5.29822

p-ISSN: 2721-8392

e-ISSN: $2655-8297$

\section{Abstract}

Every political party tries to maximize every component in the structure of their political party. One component that is in direct contact with the citizen is the wings of political parties, which is an important element in political parties to develop strategic political party programs that are indirectly not covered by political parties. There is an urgency to organize the wings of political parties as a form of the constitutional responsibility of the State for the right to associate and assemble of their own citizen; so that there is certainty to provide legal protection; and clarifying the socio-political status compared to other organizations. This article uses normative approach. The normative approach will be conducted by reviewing the Laws on specific issue of political party. Article show that there is an urgency to reform the model of constitutional legal regulations for WPP by making a special chapter on WPP and recommendations for the content of the ideal regulations for WPP.

Keywords: Arrangement; Wings of Political Parties; Political Parties.

\begin{abstract}
Abstrak
Setiap partai politik berusaha untuk memaksimalkan tiap-tiap komponen yang ada dalam struktur partainya. Salah satu komponen yang bersentuhan secara langsung dengan masyarakat adalah organisasi sayap partai, yang menjadi elemen penting dalam partai politik untuk mengembangkan program partai politik yang strategis yang secara tidak langsung dapat dicover oleh partai politik. Adanya urgensi untuk melakukan pengaturan organisasi sayap partai sebagai wujud tanggung jawab konstitusional Negara terhadap hak berserikat dan berkumpul warga negara; agar ada kepastian untuk memberikan perlindungan hukum; dan memperjelas status sosial-politik dibanding organisasi lainnya. Artikel ini menggunakan pendekatan normatif yaitu merujuk pada peraturan perundang-undangan yang berkaitan dengan partai politik. Artikel ini menunjukkan adanya urgensi untuk pembenahan model pengaturan hukum yang konstitusional terhadap OSP dengan membuat satu bab khusus tentang OSP dan rekomendasi muatan materi pengaturan yang ideal terhadap OSP.

Kata Kunci: Pengaturan; Organisasi Sayap Partai; Partai Politik.
\end{abstract}

Copyright (c) 2021 Muhammad Riyanto Zahri 


\section{Pendahuluan}

Pasca reformasi, jumlah partai politik meningkat tajam, sehingga kontestasi dalam Pemilihan Umum (Pemilu) kian hari semakin kompetitif. Setiap partai politik berusaha untuk memaksimalkan tiap-tiap komponen yang ada dalam struktur partainya. Salah satu komponen yang bersentuhan secara langsung dengan masyarakat adalah Organisasi Sayap Partai Politik yang untuk selanjutnya disebut (OSP) karena OSP menjadi sumber penting dalam kaderisasi partai politik untuk menginternalisasi ideologi partai politik dan pembangunan karakter militansi dapat lebih mudah dilakukan dibandingkan sumber kaderisasi yang berasal dari organisasi masyarakat lainnya. ${ }^{1}$

OSP memberikan andil besarbagi partai politik baik dalam upayaimplementasi, sosialisasi maupun pelaksana program dan kebijakan partai bisa dibilang sebagai faktor pelengkap bagi jalannya roda organisasi partai politik. Berdasarkan Pasal 12 huruf j Undang-Undang Nomor 2 Tahun 2008 tentang Partai Politik (UU Partai Politik) memberi hak bagi setiap partai politik untuk membentuk dan memiliki OSP. Hanya saja ketentuan dalam undang-undang tersebut tidak mengatur secara detail terkait dengan pengelolaan OSP. Undang-Undang Nomor 2 Tahun 2011 tentang Perubahan atas Undang-Undang Nomor 2 Tahun 2008 tentang Partai Politik yang menjadi penyempurna undang-undang sebelumnya tidak memberikan penjelasan secara lebih mendalam. Dalam penjelasan Pasal 12 huruf j Undang-Undang Nomor 2 Tahun 2008 tentang Partai Politik, memberikan penjelasan sederhana mengenai OSP bahwa OSP merupakan organisasi yang dibentuk oleh partai politik ataupun yang menyatakan diri sebagai OSP sesuai dengan AD/ART masing-masing partai politik dan tidak ada pengaturan yang lebih jelas mengenai OSP. OSP berbadan hukum terdaftar statusnya sebagai organisasi kemasyarakatan di dalam Kementerian Dalam Negeri sehingga melahirkan ketidaksinkronan antara legalitas partai politik

${ }^{1}$ Anwar Firmansyah, 'Relevansi Keberadaan Organisasi Sayap bagi Partai Politik: Upaya DPD Repdem DIY dalam Memperkuat Basis Sosial PDI Perjuangan Guna Menghadapi Pemilu 2014 di Provinsi Daerah Istimewa Yogyakarta', Skripsi (Program Studi S1 Ilmu Pemerintahan (Politik dan Pemerintahan) Fakultas Ilmu Sosial dan Ilmu Politik Universitas Gadjah Mada 2016).[4-5]. 
yang sah sehingga perlu dipertegas kembali apakah OSP dapat dikualifikasikan sebagai organisasi kemasyarakatan ataukah entitas dari partai politik. ${ }^{2}$

\section{Metode Penelitian}

Penelitian ini menggunakan tipologi penelitian hukum doctrinal atau Doctrinal Research. Menurut Hutchinson penelitian hukum doctrinal atau Doctrinal Research yaitu dengan melakukan pengumpulan aturan-aturan hukum yang relevan dengan isu hukum terkait kemudian melakukan analisa hubungan antar aturan-aturan hukum. ${ }^{3}$

\section{Konseptualisasi Organisasi Sayap Partai Politik}

Organisasi adalah suatu unit sosial yang dikoordinasikan dengan sadar, yang terdiri dari dua orang atau lebih, yang berfungsi atas dasar yang relatif terus menerus untuk mencapai suatu tujuan atau serangkaian tujuan bersama. ${ }^{4}$ Dalam menganalisa organisasi dapat dilakukan dua pendekatan, yaitu pendekatan objektif dan pendekatan subjektif. Pendekatan objektif memiliki makna dilakukan dengan perilaku, peristiwa serta eksistensi dalam praktek. Sementara pendekatan subjektif melihat organisasi sebagai sebuah konstruksi sosial, di mana realitas yang terjadi merupakan perwujudan dari gagasan dan ide-ide. ${ }^{5}$ Konsep organisasi mengandung beberapa elemen yang saling mempengaruhi, mulai dari orang per orang, tindakan, relasi, hubungan dan kesepakatan-kesepakatan yang melibatkan banyak orang. Dalam organisasi terjadi perbedaan-perbedaan pandangan di satukan dalam apa yang disebut dengan visi serta tujuan yang disepakati mereka terhadap berbagai kepentingan yang semula berbeda menjadi satu dalam sebuah struktur. Pengertian sayap adalah bagian tubuh beberapa binatang (burung dan sebagainya

\footnotetext{
${ }^{2}$ Direktorat AHU, 'Organisasi sayap politik dan kejelasan payung hukum' (UII 2019)< https;//www.uii.ac.id/organisasi-sayap-politik-dan-kejelasan-payung-hukum> accesed 19 agustus 2019.

${ }^{3}$ Peter Mahmud Marzuki, Penelitian Hukum (Kencana 2006).[32].

${ }^{4}$ Stephen P Robins, Perilaku Organisasi (PT Indeks Gramedia 2006).[4].

${ }^{5}$ Don F F Pace, Komunikasi Organisasi: Strategi Meningkatkan Kinerja Perusahaan, terjemahan (PT Remaja Rosdakarya 2011).[11].
} 
yang digunakan untuk terbang. ${ }^{6}$ Definisi ini bila ditelaah ke dalam organisasi partai politik, maka dapat disusun pengertian sayap sebagai bagian dari organisasi partai politik yang dipergunakan untuk mengembangkan program-program partai politik yang menguntungkan bagi organisasi tersebut. Partai politik menurut Pasal 1 ayat (1) UU No. 2 Tahun 2008 adalah organisasi yang bersifat nasional dan dibentuk oleh sekelompok warga negara Indonesia secara sukarela atas dasar kesamaan kehendak dan cita-cita untuk memperjuangkan dan membela kepentingan politik anggota, masyarakat, bangsa dan negara, serta memelihara keutuhan Negara Kesatuan Republik Indonesia berdasarkan Pancasila dan Undang-Undang Dasar Negara Republik Indonesia Tahun 1945. Menurut Jimly Asshiddiqie, partai politik merupakan pilar yang sangat penting untuk diperkuat derajat pelembagaannya dalam setiap sistem politik yang demokratis. ${ }^{7}$ Berdasarkan pengertian istilah organisasi, sayap dan partai politk dapat dirumuskan menjadi sebuah konsep organisasi sayap partai yaitu, kumpulan beberapa orang yang terstruktur dengan visi politik yang sama untuk mewujudukan tujuan partai politik yang membentuknya. Dengan demikian, organisasi sayap partai merupakan organisasi yang menyatu dengan organisasi partai politik, baik dibentuk oleh partai politik maupun memiliki tujuan yang sama sesuai dengan yang telah ditetapkan oleh partai politik melalui AD/ART.

OSP merupakan organisasi dianggap penting keberadaannya dalam rangka mengoptimalkan tugas dan fungsi partai sekaligus menunjang eksistensi partai yang menaunginya. Di Amerika Serikat, OSP diidentifikasikan sebagai kelompok berkepentingan (interest group) yang mempunyai hubungan yang dekat dengan partai politik dimana keduanya dikategorikan sebagai tipe asosiasi politik yang menjadi perantara hubungan antara warga Negara dan pemerintah. Interest group dapat dijadikan kesempatan efektif untuk berpartisipasi terorganisir dan efisien untuk proses pengambilan keputusan pada sebuah kebijakan publik. ${ }^{8}$ OSP dalam

\footnotetext{
${ }^{6}$ KBBI Online, 'Sayap', (Badan Pengembangan dan Pembinaan Bahasa 2012) $<$ https://kbbi. web.id/sayap> accessed 12 oktober 2019.

${ }^{7}$ Jimly Asshiddiqie, Pengantar Ilmu Hukum Tata Negara (Rajawali Press 2014).[401].

${ }^{8}$ Rosa Ristawati dan Radian Salman, 'Partai Politik dan Organisasi Sayap di Indonesia: Fungsi dan Pengaturannya'(2019) Fakultas Hukum Universitas Airlangga.[3-6].
} 
menjalankan tugas dan fungsinya, baik fungsi yang idealis sesuai dengan AD/ART maupun fungsi yang pragmatis demi menunjang keberlangsungan kebijakan partai, tentu saja partai tidak dapat bekerja sendiri. Partai politik kemudian menciptakan OSP guna aktualisasi program kerja beserta fungsi-fungsi partai politik. OSP merupakan organisasi yang berada dibawah kontrol partai politik. sering disebut juga onderbouw politik. Menurut National Democratic Institute, kebanyakan partai politik di berbagai belahan dunia ini mempunyai kelompok-kelompok yang karakteristiknya sama dengan organisasi sayap partai dan berafiliasi dengan partai politik. Kelompok-kelompok ini berdiri berdasarkan basis segmentasi keanggotaan seperti kaum pemuda, kaum perempuan, atau berbasis isu yang menjadi fokus gerakannya, keberadaan kelompok-kelompok ini berguna untuk memobilisasi partisipasi dalam aktifitas politik. ${ }^{9}$ Peran kelompok ini juga dapat ditunjukan melalui program yang lebih berkualitas dan mempunyai manfaat yang nyata bagi orang yang tergabung kedalam kelompok tersebut sehingga bisa mengelola isu secara efektif dan efisien yang menjadi fokus kelompok tersebut karena orang yang tergabung punya visi yang sama dalam mencapai tujuan. Sebagai contoh tahun 2006, The Canadian Liberal Women's Caucus, sebuah kelompok dengan segmentasi perempuan yang mempunyai karakteristik OSP meluncurkan sebuah dokumen yang berisi opini yang memastikan bahwa kebijakan-kebijakan dengan perspektif feminis untuk : early learning and child care, income security, improved maternity and parental benefit..$^{10}$

Keberadaan OSP menimbulkan konsekuensi perlunya pengakuan oleh partai politik terhadap suatu entitas terhadap OSP. Problematika mengenai hal ini sampai saat ini belum diakui walaupun sudah dibandingkan dengan karakteristik dari organisasi antara OSP dengan organisasi kemasyarakatan. Namun demikian, diperlukan pengaturan yang bersifat sui generis yang menjadi rujukan lengkap bagi

\footnotetext{
${ }^{9}$ National Democratic Institute, 'Political Parties and Democracy In Theoretical And PracticalPerspectives Develponing Party Policies’ (2013) diakses dari< https://www.ndi.org/sites/ default/files/FINAL-Policy- Development-PDF-2.pdf $>$ diunduh pada tanggal 10 Oktober 2019.[25].

${ }^{10} \mathrm{ibid}$.
} 
OSP. Kejelasan pengaturan mengenai kelembagaan OSP harus memiliki maksud dalam mewujudkan upaya untuk mendorong demokratisasi dan konsolidasi demokrasi di Indonesia dengan harapannya dapat mendorong pendidikan politik yang selama ini dinilai tidak berhasil dilakukan oleh partai politik ditiap wadah kontestasi politik. ${ }^{11}$ Dalam sistem ketatanegaraan, melihat kedudukan hukum yang mengatur OSP telah didukung salah satu instumen yaitu Pasal 12 huruf J Undang-Undang Parpol bahwa parpol berhak untuk membentuk dan memiliki OSP. Secara pengaturan jelas bahwa kedudukan OSP sebagai underbow dari parpol yaitu sebagai pendukung kinerja dari partai politik agar partai politik dapat menjalankan peran dan fungsinya seperti seharusnya. Dalam penjelasan Pasal 12 huruf J Undang-Undang Partai Politik tersebut semakin jelas bahwa OSP memang bagian internal dari partai politik karena OSP dibentuk ataupun menyatakan diri sesuai dengan AD/ART partai politik. Jadi OSP menurut peraturan sesuai dengan konstitusi yang berlaku dapat dibentuk baik oleh partai politik maupun atas kemauan sendiri dari organisasi tertentu dalam masyarakat dengan mengikuti AD/ART partai politik terkait.

\section{Pengaturan Organisasi Sayap Partai: Studi Kasus Beberapa AD/ART Partai Politik}

Kekosongan hukum terhadap pengaturan OSP tentu menimbulkan dilemma bagi OSP dalam menjalankan aktifitasnya di tengah-tengah masyarakat. Sebagai organisasi yang bekerja untuk kepentingan partai politik, simbol, bahasa, dan lambang partai sering melekat pada OSP di satu sisi, sementara di sisi lain, tidak jarang OSP bergerak di tengah- tengah masyarakat layaknya sebuah ormas yang melekatkan dirinya dengan aktifitas-aktifitas sosial kemasyarakatan, dan bahkan kegiatan keagamaan yang nota bene merupakan lahan kegiatan ormas. Apabila kegiatan ormas di bebani dengan berbagai peraturan dalam melaksanakan kegiatan, berbeda dengan OSP, OSP dapat memiliki kegiatan bahkan melebihi cakupan

\footnotetext{
${ }^{11}$ Anwar Firmansyah, Op.Cit.[4].
} 
kegiatan Ormas, namun dianggap hanya sebagai bagian dari kegiatan partai politik. Beberapa tinjauan terhadap Anggaran Dasar (AD) dan Anggaran Rumah Tangga (ART) Partai Politik, seperti PD-P, Gerindra, Golkar dan PKS memperlihatkan bagaimana Partai Politik menempatkan posisi OSP:

a. PDI-P

Partai Demokrasi Indonesia Perjuangan (PDI-P) dalam AD/ART nya tidak ditemui istilah OSP, melainkan hanya dikenal istilah Komunitas Juang Partai sebagaimana diatur Pasal 54 Anggaran Dasar PDI-P :

1) Komunitas Juang Partai berbentuk unit kerja,organisasi sayap, organisasi kemasyarakatan dan organisasi-organisasi lainnya.

2) Komunitas Juang Partai bertugas melakukan pengorganisiran rakyat sesuai jenis komunitasnyasebagai upaya penggalangan pemilih di luar basis Partai. $^{12}$

b. Partai Gerindra

Partai Gerakan Indonesia Raya (Gerindra) dalam AD/ART nya mengatur tentang OSP dalam Bab IX Pasal 27 sebagai berikut:

1) Dewan Pimpinan Pusat Partai GERINDRA membentuk Organisasi Sayap di tingkat pusat sebagai sumber anggota atas persetujuan Ketua Dewan Pembina. 2) Organisasi Sayap Partai GERINDRA tingkat pusat yang dinyatakan sah adalah organisasi sayap yang telah ditetapkan berdasarkan Surat Keputusan Dewan Pimpinan Pusat atas persetujuan Ketua Dewan Pembina.

2) Pengesahan susunan personalia Pimpinan Pusat Organisasi Sayap Partai GERINDRA ditetapkan oleh Dewan Pimpinan Pusat Partai GERINDRA atas persetujuan Ketua Dewan Pembina.

3) Pengesahan susunan personalia Organisasi Sayap Partai GERINDRA di tingkat Provinsi, Kabupaten/Kota dan Kecamatan ditetapkan oleh Pimpinan Pusat Organisasi Sayap masing-masing.

4) Pengaturan lebih lanjut ketentuan sebagaimana dimaksud pada ayat (1), ayat (2), ayat (3) dan ayat (4) diatas diatur dalam Anggaran Rumah Tangga. ${ }^{13}$

\footnotetext{
${ }^{12}$ AD/ART Partai Demokrasi Indonesia Perjuangan (PDIP) Periode 2015-2020.

${ }^{13}$ AD/ART Partai Gerindra ditetapkan di Jakarta, Tanggal 20 Oktober 2014.
} 


\section{c. Partai Golkar}

Partai Golongan Karya (Golkar) mengatur mengenai OSP dalam Bab X Pasal 25

AD Partai Golkar, dengan rumusan sebagai berikut:

1) Partai GOLKAR memiliki Organisasi Sayap yang merupakan wadah perjuangan sebagai pelaksana kebijakan partai yang dibentuk untuk memenuhi kebutuhan strategis, dalam rangka memperkuat basis dukungan partai;

2) Pembentukan Organisasi Sayap diusulkan oleh Dewan Pimpinan Pusat dan ditetapkan oleh Rapat Pimpinan Nasional;

3) Pengaturan lebih lanjut tentang Organisasi Sayap diatur dalam Anggaran Rumah Tangga.

Sementara ketentuan lebih lanjut diatur dalam ART sebagaimana terdapat dalam BAB VII tentang Kedudukan dan Tugas Organisasi Sayap Partai, Pasal 21:

1) Organisasi Sayap dapat dibentuk di setiap tingkatan Partai;

2) Partai Golongan Karya memiliki Organisasi Sayap Perempuan, yaitu Kesatuan Perempuan Partai Golongan Karya (KPPG) dan Organisasi Sayap Pemuda yaitu Angkatan Muda Partai Golongan Karya (AMPG) dan dapat membentuk Organisasi Sayap lainnya sesuai dengan kebutuhan dan kepentingan Partai;

3) Organisasi Sayap di setiap tingkatan memiliki struktur organisasi șépidankewenangan untuk mengelola dan melaksanakan kegiatan organisasi sesuai bidang/kelompok strategisnya, yang dalam pelaksanaannya dipertanggungjawabkan pada Dewan Pimpinan Partai sesuai tingkatannya;

4) Organisasi Sayap tingkat Pusat/Provinsi/Kabupaten/Kota/Kecamatan melaksanakan pembinaan dan pengawasan organisasi yang berada satu tingkat dibawahnya;

5) Kepengurusan Organisasi Sayap ditetapkan oleh Dewan Pimpinan/Pimpinan Partai sesuai tingkatannya;

6) Ketua Umum dan Ketua-Ketua Organisasi Sayap sesuai tingkatannya secara ex officio dijabat oleh Wakil Ketua terkait pada DewanPimpinan/Pimpinan Partai ditingkatannya; istep?

7) Ketentuan lebih lanjut mengenai Organisasi Sayap diatur dalamPeraturan Organisasi.

Membaca ketentuan OSP oleh masing-masing partai politik, minimal terhadap tiga partai politik di atas, terlihat bahwa OSP merupakan bagian yang melekat dengan kepentingan dan tujuan partai politik.OSP tidak terpisah dengan 
organisasi partai politik, mulai dari tingkat pusat sampai ke daerah.Oleh karena OSP merupakan hak partai politik, maka pengaturan terhadap OSP menjadi kewenangan masing-masing partai politik.OSP tidak diatur oleh peraturan perundang- undangan lainnya, kecuali oleh produk hukum internal partai politik itu sendiri.Dengan demikian, seluruh pertanggungjawaban OSP bersifat vertikal kepada organisasi induknya. Sekalipun seluruh kegiatan OSP terkait langsung dengan masyarakat non pendukung partai politik OSP, OSP dengan perannya mengembankan program partai politik di setiap lapisan kepengurusan, keberadaannya tetap berada dalam organisasi partai politik, dan karena itu, OSP menjadi terbuka untuk bekerja sama dengan kelompok sosial masyarakat.

\section{Dasar Konstitusionalitas}

Sebagai negara penganut demokrasi, maka negara Indonesia wajib memberi pengakuan, perlindungan serta penjaminan terhadap hak asasi manusia (HAM) bagi seluruh rakyat karena esensi dari demokrasi itu sendiri adalah HAM. Salah satu unsur HAM yang penting adalah kebebasan berserikat, berkumpul dan berpendapat. Undang-Undang Dasar Negara Republik Indonesia Tahun 1945 yang selanjutnya disebut (UUD NRI Tahun 1945) secara konsisten mengamanatkan serta mengoptimalkan makna dari kebebasan tersebut. Pertimbangan mengenai materi pengaturan kebebasan berserikat, berkumpul dan berpendapat jika dicermati tidak diubah pada waktu amandemen UUD 1945 sebagaimana tercantum dalam Pasal 28 UUD Tahun NRI 1945. Penjaminan atas kebebasan berserikat, berkumpul dan berpendapat itu kemudian menjadi landasan terbentuknya partai politik, diketahui sebagai wadah demokrasi guna memperjuangkan tercapainya tujuan dan cita-cita bersama bangsa Indonesia yang adil, damai dan makmur. ${ }^{14}$ Undang-Undang No 2 Tahun 2008 tentang partai politik yang selanjutnya disebut UU Parpol kemudian mendudukan partai politik sebagai unsur penting dalam pelaksanaan demokrasi,

\footnotetext{
${ }^{14}$ Bagian menimbang (a) menunjukkan adanya pertimbangan terkait kebebasan berserikat dan berkumpul, dalam UU Nomor 2 Tahun 2008 yang telah diubah menjadi UU Nomor 2 Tahun 2011 tentang Partai Politik.
} 
akan tetapi realitas partai politik terhadap kekuasaan senada dengan pandangan Miriam Budiardjo yang menyatakan bahwa partai politik adalah suatu kelompok yang terorganisir yang anggota-anggotanya mempunyai orientasi, nilai-nilai dan cita-cita yang sama, tujuan kelompok ini adalah untuk memperoleh kekuasaan politik dan berebut kekuasaan politik dengan cara yang ditetapkan secara konstitusional untuk melaksanakan kebijakan dan program-program mereka. ${ }^{15}$

Sebagaimana dipahami bahwa kebebasan berserikat dan berkumpul merupakan salah satu bentuk dari hak asasi manusia yang harus dilindungi negara yang menganut demokrasi. Deklarasi Universal HAM Internasional pada tahun 1948 dalam Pasal 20 menyatakan bahwa : (1) Everyone has the right for freedom of peaceful assembly and association; (2) No one may be compelled to belong to an association. Pertimbangan mengenai hal ini perlu diingat bahwa pengaturan tentang setiap orang memiliki kebebasan berserikat dan berkumpul sudah lebih dulu diatur dalam UUD 1945 yaitu pada Pasal 28 yaitu: kemerdekaan berserikat dan berkumpul, mengeluarkan pikiran dengan lisan dan tulisan dan sebagainya ditetapkan dengan Undang-Undang. Dalam muatan Pasal tersebut dapat dipastikan UUD yang berlaku selalu memberi pengakuan tegas terhadap kebebasan berkumpul dan berserikat. ${ }^{16}$ Kebebasan berserikat dan berorganisasi adalah bagian dari hak konstitusional warga negara yang dijamin dan dilindungi oleh konstitusi sebagaimana tertuang dalam Pasal 28 dan Pasal 28E ayat (3) UUD NRI Tahun 1945. Pasal 24 Undang-Undang Nomor 39 Tahun 1999 tentang Hak Asasi Manusia yang selanjutnya disebut (UU No 39 Tahun 1999) menegaskan bahwa: (1) setiap orang berhak untuk berkumpul, berpendapat, dan berserikat, untuk maksud-maksud damai, dan (2) setiap warga negara dan kelompok masyarakat berhak mendirikan partai politik, lembaga swadaya masyarakat atau organisasi lainnya untuk berperan

${ }^{15}$ Miriam Budiardjo, Dasar-Dasar Ilmu Politik (Gramedia Pustaka Utama 2008).[403-404].

${ }^{16}$ Pengaturan terkait kebebasan berkumpul dan berserikat: yaitu dalam Pasal 28E ayat (3): Setiap orang berhak atas kebebasan berserikat, berkumpul dan mengeluarkan pendapat. Terkait pengakuan kebebasan berserikat dan berkumpul ini dalam dalam UUD RIS 1949 dan UUD Sementara 1950 masing masing dimuat dalam Pasal 20, di dalam UUD 1945 Perubahan, Pasal 28 tidak diubah yang berarti muatan pengaturan Pasal 28 UUD 1945 Perubahan tetap seperti bunyi pasal 28 UUD 1945 asli. 
serta dalam jalannya pemerintahan dan penyelenggaraan negara sejalan dengan tuntutan perlindungan, penegakan, dan pemajuan hak asasi manusia sesuai dengan ketentuan peraturan perundang-undangan. Kebebasan berserikat juga merupakan salah satu hak fundamental yang menjadi perhatian seluruh umat manusia di dunia. Pasal 22 UU Nomor 12 Tahun 2005 tentang Pengesahan Internasional Covenant On Civil and Political Rights (Kovenan Internasional tentang Hak-Hak Sipil dan Politik) juga mengatur: (1) setiap orang berhak atas kebebasan untuk berserikat dengan orang lain, termasuk hak untuk membentuk dan bergabung dalam serikat pekerja untuk melindungi kepentingannya; (2) tidak diperkenankan untuk membatasi pelaksanaan hak ini, kecuali yang telah diatur oleh hukum, dan yang diperlukan dalam masyarakat demokratis untuk kepentingan keamanan nasional dan keselamatan publik, ketertiban umum, perlindungan kesehatan dan moral umum, atau perlindungan atas hak dan kebebasan dari orang lain. Pasal ini tidak boleh mencegah diberikannya pembatasan yang sah bagi anggota angkatan bersenjata dan kepolisian dalam melaksanakan hak ini; dan (3) Tidak ada satu hal pun dalam pasal ini yang memberikan kewenangan kepada Negara Pihak Konvensi Organisasi Buruh Internasional Tahun 1948 tentang Kebebasan Berserikat dan Perlindungan Atas Hak Berserikat untuk mengambil tindakan legislatif atau menerapkan hukum sedemikian rupa, sehingga dapat mengurangi jaminan-jaminan yang diberikan dalam konvensi tersebut.

OSP merupakan salah satu bentuk kebebasan berserikat dan berorganisasi yang dimiliki oleh OSP karena kebebasan berserikat merupakan bagian dari hak konstitusional warga negara yang dijamin dan dilindungi oleh konstitusi seperti yang diuraikan legal standing diatas. ${ }^{17}$ Konstitusionalitas suatu organisasi sayap partai politik dapat kita lihat sesuai dengan Putusan Mahkamah Konstitusi Perkara Nomor 82/PUU-XI/2013 yang diuraikan dalam pertimbangan hukum angka [3.17] sampai dengan angka [3.19.9], menguraikan bahwa hakikat demokrasi pada umumnya (secara universal) memberikan otonomi yang luas kepada kebebasan manusia atau

\footnotetext{
${ }^{17}$ Bentuk implementasi dari pelaksanaan UUD NRI 1945 Pasal 28 salah satunya dibentuk organisasi sayap partai politik.
} 
badan hukum sebagai warga di dalam suatu negara. Demokrasi sangat menghormati serta menjunjung tinggi harkat dan martabat manusia (human dignity). Dari sinilah hubungan antara hak asasi manusia dan demokrasi sebagai model penyelenggaraan pemerintahan suatu negara tidak dapat dipisahkan. Pemerintahan demokrasi adalah pemerintahan yang memberi peran kunci kepada rakyat sebagai pemilik kedaulatan, segala kebijakan pemerintahan ditentukan oleh rakyat, dilaksanakan oleh rakyat melalui organ kekuasaan yang dibentuk oleh rakyat serta penyelenggaraan pemerintahan yang selalu diawasi oleh rakyat agar tidak menyimpang dari kehendak rakyat. ${ }^{18}$ Pemerintahan demokrasi memberi peran dan otonomi luas kepada rakyat untuk berpartisipasi dalam pemerintahan baik secara langsung atau melalui perwakilan dalam perumusan dan pembentukan norma hukum serta kebijakan dalam pemerintahan negara. ${ }^{19}$ Nilai dan prinsip demokrasi dirumuskan dalam Pembukaan UUD NRI 1945 yaitu “...maka disusunlah Kemerdekaan Kebangsaan Indonesia itu dalam suatu Undang-Undang Dasar Negara Republik Indonesia, yang terbentuk dalam suatu susunan Negara Republik Indonesia yang berkedaulatan rakyat dengan berdasar kepada Ketuhanan yang maha Esa, Kemanusiaan yang adil dan beradab, Persatuan Indonesia, dan Kerakyatan yang dipimpin oleh hikmat kebijaksanaan dalam Permusyawaratan/Perwakilan, serta dengan mewujudkan suatu keadilan sosial bagi seluruh rakyat Indonesia”. Untuk itu, Pasal 1 ayat (2) UUD NRI 1945 menyatakan, "Kedaulatan berada di tangan rakyat dan dilaksanakan menurut Undang-Undang Dasar”. Model pemerintahan yang berdasar kedaulatan rakyat adalah model pemerintahan demokrasi karena menempatkan kedaulatan rakyat sebagai pemilik kedaulatan tertinggi. ${ }^{20}$

UUD NRI 1945 menegaskan jaminan dan pengakuan atas hak-hak asasi manusia dan mengatur bahwa pemerintahan yang melaksanakan kekuasaan negara

\footnotetext{
${ }^{18}$ Purwati Soeprapto, 'Pidato Presiden Lincoln' (Voa Indonesia 2004) <www.voaindonesia. com> accessed 02 Oktober 2019.

${ }^{19}$ Lailatin Mafiroh, 'Partisipasi Masyarakat Dalam Penyelenggaraan Good Governance', (Kompasiana 2018) <www.kompasiana.com> accessed 02 Oktober 2019.

${ }^{20}$ Soewoto Mulyosudarmo, Pembaharuan Ketatanegaraan Melalui Perubahan Konstitusi (Asosiasi Pengajar HTN dan HAN dan In-TRANS 2004).[3].
} 
adalah pemerintahan yang dipilih oleh rakyat baik yang dipilih secara langsung maupun tidak langsung oleh rakyat. UUD NRI 1945 memberi ruang kebebasan kepada rakyat untuk mengawasi dan berpartisipasi dalam pemerintahan negara dengan memberikan jaminan hak dan kebebasan kepada setiap orang untuk mengeluarkan pendapat, berkumpul dan berserikat. Prinsip kebebasan berserikat dan berkumpul secara tegas ditentukan dalam Pasal 28 NRI UUD 1945 yang menyatakan, "Kemerdekaan berserikat dan berkumpul, mengeluarkan pikiran dengan lisan dan tulisan dan sebagainya ditetapkan dengan undang-undang”. Kemudian, Pasal 28E ayat (3) UUD NRI 1945 menyatakan, "Setiap orang berhak atas kebebasan berserikat, berkumpul, dan mengeluarkan pendapat”. Dengan demikian, setiap orang berhak dan bebas membentuk atau ikut serta keanggotaan atau pun menjadi pengurus organisasi dalam kehidupan bermasyarakat dalam wilayah Negara Republik Indonesia. Kebebasan berserikat dan mengeluarkan pendapat adalah termasuk salah satu prinsip negara demokrasi. Namun demikian, menurut UUD NRI 1945, dalam menjalankan hak kebebasan berserikat dan berkumpul bukan tidak tak terbatas. Kebebasan tersebut dibatasi oleh tanggung jawab dan kewajiban dalam hubungan dengan orang lain, masyarakat, bangsa, dan negara. Kebebasan berserikat dan menyatakan pendapat adalah hak asasi manusia yang dijamin oleh konstitusi, namun kebebasan tersebut dapat dibatasi oleh negara melalui ketentuan Undang-Undang dalam batas-batas tertentu yang diperkenankan oleh konstitusi, yaitu dengan maksud semata-mata untuk menjamin pengakuan serta penghormatan atas hak dan kebebasan orang lain dan untuk memenuhi tuntutan yang adil sesuai dengan pertimbangan moral, nilai-nilai agama, keamanan, dan ketertiban umum dalam suatu masyarakat demokratis (Pasal 28J ayat (2) UUD NRI 1945).

\section{Politik Hukum Pengaturan Organisasi Sayap Partai}

Hukum adalah sebuah entitas yang sangat kompleks, meliputi kenyataan kemasyarakatan yang majemuk, mempunyai banyak aspek, dimensi dan fase 
sehingga proses interaksi dibentuk dan ikut membentuk tatanan masyarakat. ${ }^{21}$ Kompleksitas tersebut menyebabkan lahirnya berbagai disiplin ilmu hukum salah satunya adalah politik hukum. Masing-masing ragam disiplin hukum di atas bisa disikapi sebagai disiplin ilmu yang berdiri sendiri, namun bukan berarti kesemuanya bekerja secara sendiri-sendiri, perihal sesungguhnya kesemuanya saling berkaitan satu sama lain. Disiplin hukum merupakan ilmu bantu yang dapat dimanfaatkan sebagai pendekatan yang secara sinergis bekerja secara komprehensif berdasarkan susunan yang sistematis sehingga dapat menggali dan menjelaskan apa sesungguhnya hukum itu dan bagaimana proses pembentukan hukum itu dapat dijelaskan dengan baik. ${ }^{22}$

Politik menurut Otto Von Bismarck adalah mempertaruhkan kemungkinan untuk merebut kemungkinan yang lebih besar. Berarti, ada nilai yang diperjuangkan, ada tujuan yang hendak diraih. Dengan demikian politik mengandung sifat eksistensial dalam wujudnya, karena melibatkan juga rasionalitas nilai-nilai atau Wertrationalitaet dalam pengertian Weber. Politik memiliki mandat mencapai tujuan. Tujuan yang dipilih adalah tujuan sesuai sistem yang lebih besar, yang dipandu rasionalitas nilai. Dengan demikian maka politik hukum berbicara nilai dan tujuan yang hendak diraih. Dalam pandangan Gustav Radbruch, hukum bicara pengaturan keadilan, serta memastikan keadilan itu terwujud di bawah jaminan aturan yang jelas-tegas, sehingga memberi manfaat pada kebaikan manusia Dan itulah supremasi keadilan. ${ }^{23}$ Secara tegas dapat dikatakan bahwa politik hukum penataan pengaturan organisasi sayap partai adalah untuk memberikan perlindungan hukum, pemenuhan hak berserikat dan berkumpul dalam kerangka pelembagaan partai politik agar dapat menjalankan fungsi dan meraih tujuannya dalam konteks pengembangan demokrasi Pancasila.

\footnotetext{
${ }^{21}$ Bernard Arief Sidharta, Refleksi tentang Struktur Ilmu Hukum: Sebuah Penelitian tentang Fondasi Kefilsafatan dan Sifat Keilmuan Ilmu Hukum sebagai Landasan Pengembangan Ilmu Hukum Nasional Indonesia (Mandar Maju 1999).[16].

${ }^{22}$ Imam Syaukani dan A. Ahsin Thohari, Dasar-dasar Politik Hukum (Rajawali Press 2012).[3].

${ }^{23}$ Bernard L. Tanya, Politik Agenda Kepentingan Bersama (Genta Publishing 2011).[1-2].
} 
Bagaimana materi muatan pengaturannya? Secara garis besar sebagai berikut:

1) Bentuk OSP;

2) Hak dan Kewajiban OSP;

3) Pertanggungjawaban Hukum OSP;

4) Mekanisme Pembentukan OSP;

5) Peran dan Partisipasi OSP;

6) Sanksi dan Pembubaran OSP.

\section{Kesimpulan}

OSP merupakan organisasi murni di didirikan di atas kepentingan partai politik, sehingga dengan demikian OSP mesti dibedakan secara tegas dengan Ormas. OSP tidak dapat dijadikan sebagai Ormas, sekalipun dalam praktek kegiatan-kegiatan OSP sering menyerupai kegiatan Ormas. Pembedaan antara OSP dengan Ormas tidak saja oleh karena dasar dan tujuan berdirinya, akan tetapi, perlu ditetapkan batasan-batasan normatif sehingga antara OSP dengan Ormas tidak saling bertabrakan dalam melakukan aktifitas kemasyarakatannya di tengah-tengah masyarakat.

Adanya urgensi untuk melakukan penataan pengaturan OSP sebagai wujud tanggung jawab konstitusional Negara terhadap hak berserikat dan berkumpul warga negara; agar ada kepastian untuk memberikan perlindungan hukum; memperjelas status sosial-politik dibanding organisasi lainnya. Pengaturan diperlukan dalam konteks memperjelas hubungan hukum antara OSP dengan partai politik pembentuknya.

\section{Daftar Bacaan}

\section{Buku}

Bernard Arief Sidharta, Refleksi struktur Ilmu Hukum: Sebuah Penelitian tentang Fondasi Kefilsafatan dan Sifat Keilmuan Ilmu Hukum sebagai Landasan Pengembangan Ilmu Hukum Nasional Indonesia (Mandar Maju 1999).

Bernard L. Tanya, Politik Agenda Kepentingan Bersama (Genta Publishing 2011). 
Imam Syaukani dan A. Ahsin Thohari, Dasar-dasar Politik Hukum (Rajawali Press 2012).

Jimly Asshiddiqie, Pengantar Ilmu Hukum Tata Negara (Rajawali Press 2014).

Miriam Budiardjo, Dasar-Dasar Ilmu Politik (Gramedia Pustaka Utama 2008).

National Democratic Institute, Political Parties and Democracy In Theoretical And Practical Perspectives, Developing Party Policie (National Democratic Institute 2013).

Peter Mahmud Marzuki, Penelitian Hukum (Kencana 2005).

R. Wayne Pace Don F, Komunikasi Organisasi: Strategi Meningkatkan Kinerja Perusahaan, terjemahan (PT Remaja Rosdakarya 2011).

Soewoto Mulyosudarmo, Pembaharuan Ketatanegaraan Melalui Perubahan Konstitusi, (Asosiasi Pengajar HTN dan HAN dan In-TRANS 2004).

Stephen P Robins, Perilaku Organisasi (PT Indeks Gramedia 2006).

\section{Skripsi}

Anwar Firmansyah, 'Relevansi Keberadaan Organisasi Sayap bagi Partai Politik: Upaya DPD Repdem DIY dalam Memperkuat Basis Sosial P D I Perjuangan Guna Menghadapi Pemilu 2014 di Provinsi Daerah Istimewa Yogyakarta' (2016) Skripsi pada Program Studi S1 Ilmu Pemerintahan (Politik dan Pemerintahan) Fakultas Ilmu Sosial dan Ilmu Politik Universitas Gadjah Mada.

\section{Jurnal}

Rosa Ristawati dan Radian Salman, 'Partai Politik dan Organisasi Sayap di Indonesia: Fungsi dan Pengaturannya' (2019) Fakultas Hukum Universitas Airlangga.

\section{Laman}

Direktorat AHU, 'Organisasi sayap politik dan kejelasan payung hukum' (2019) $<$ https://www.uii.ac.id/organisasi-sayap-politik-dan-kejelasan-payunghukum/> accesed 19 agustus 2019.

KBBI Online, 'Sayap', (Badan Pengembangan dan Pembinaan Bahasa 2012)< https://kbbi.web.id/sayap> accessed 12 oktober 2019. 
Lailatin Mafiroh, 'Partisipasi Masyarakat Dalam Penyelenggaraan Good Governance', (Kompasiana 2018) <www.kompasiana.com> accessed 02 Oktober 2019.

Purwati Soeprapto, 'Pidato Presiden Lincoln', (Voa Indonesia 2004) <www. voaindonesia.com> accessed 02 Oktober 2019.

\section{Perundang-undangan}

Undang-Undang Dasar Negara Republik Indonesia Tahun 1945.

Undang-Undang Nomor 39 Tahun 1999 tentang Hak Asasi Manusia.

Undang-Undang Nomor 12 Tahun 2005 tentang Pengesahan Covenant On Civil and Political Rights (Kovenan Internasional tentang Hak-Hak Sipil dan Politik Internasional tentang Hak-Hak Sipil dan Politik.

Undang-Undang Nomor 2 Tahun 2008 tentang Partai Politik.

Undang-Undang Nomor 2 Tahun 2011 tentang Perubahan atas Undang-Undang Nomor 2 Tahun 2008 tentang Partai Politik. 
Muhammad Riyanto: Problematika Pengaturan Organisasi...

--halaman ini sengaja dibiarkan kosong-- 